of the eflects of imipramine on behavior may involve a change in the level of 5-HT at receptor site in the brain. A further investigation is now underway to determine the effects of 5 hydroxytryptophan, a 5-HT precursor, and related catccholamines on these bchavioral measures.

\title{
REFERENCES
}

1) Kamfyama, T., Shigehisa, T.: Japan. J. Pharmacol, 23, Suppl. 62 (1973): 2) Kameyama, T., Shighilisa, T.: Japan. J. Pharmacol., 23, Stuppl. 63 (1973); 3) Carlsson, A., Corrodi, H., Fuxe, K., Hökfelt, T.: Lurop. J. Pharmacol., 5, $357(1969)$; 4) Carlsson, A.: J. Pharm. Pharmacol., 22, 729 (1970); 5) Shaskan, F.G., Snyplr, S.H.: J. Pharmacol. exp. Ther, 175, 404 (1970); 6) Sheard, M.H., Zolovick, A., Aghajanian, G.K.: Brain Res., 43, 690 (1972); 7) Snyulr, S.H., Axflrod, J., Zweig, M.: Biochem, Pharmacol., 14, 831 (1965)

\section{PRE- AND POST-SYNAPTIC ORIGIN OF LITHIUM- INDUCED ACUTE BLOCKADE ON ADRENERGIC TRANSMISSION IN RABBIT HEART}

\author{
Yoshimi MISU, Yasushi KURAISHI and Hiroshi TAKAGI \\ Department of Pharmacology, Faculty of Pharmaceutical Sciences, \\ Kyoto Lniversity, Sakyo-ku, Kyoto 606, Japm
}

Acepled Seplember 18, 1975

Lithium is being clinically prescribed for patients in the manic phase of manic depressive psychosis. There are reports that lithium interferes with metabolism (1-3) and release of noradrenaline (4) in the brain and that iontophoretically applied lithium antagonises a noradrenaline-induced inhibition of hippocampal spontancous firing activity in rats (5). The present experiment was carried out to investigate the action of lithium on the adrenergic transmission in perfused rabbit hearts with sympathetic trunks as a model. Pre- and postsynaptic responses to nerve stimulation could thus be obtained simultaneously.

The hearts with bilateral sympathetic trunks from 33 rabbits of either sex, 1.6 to $2.0 \mathrm{~kg}$, were isolated and perfused with Krebs bicarbonatc solution gassed with $5 \% \mathrm{CO}_{2}$ in oxygen as described previously (6). Temperature of the solution was kept at $30^{\circ} \mathrm{C}$. The perfusion pressure was $60 \mathrm{~cm} \mathrm{H}_{2} \mathrm{O}$ and the rate was 10 to $15 \mathrm{ml} / \mathrm{min}$. The extreme upper thoracic region of nerves was stimulated through ring electrodes similar to those described by Garry and Gillespie (7) with supramaximal rectangular pulses of $3.5 \mathrm{msec}$ duration at a frequency of $30 \mathrm{~Hz}$. The nerves were stimulated 6 times, cach of $30 \mathrm{sec}$ duration with a $30 \mathrm{sec}$ resting period. This 6 min stimulation-rest procedure is referred to as the 1 st procedure. The 2nd procedure was performed similarly $30 \mathrm{~min}$ after the beginning of the 1 st procedure. The venous effluent was collected for each $6 \mathrm{~min}$ procedure period and noradrenaline was measured fluorometrically by the methods of Anton and Sayre (8).

Some hearts were suspended by means of a perfusion apparatus KN-206 (Natsume) 
for recording contractile responses to exogenously applied noradrenaline or isoproterenol. Responses were recorded on smoked paper with a semi-isotonic lever. Student's t-test was used to evaluate data.

In untreated hearts, the amount of noradrenaline released during the 1st procedure varied from 93 to $711 \mathrm{ng}$. The mean was $311.8 \pm 93.9 \mathrm{ng}$. During the 2 nd procedure, as shown in Fig. 1-A (right ordinate), the output of noradrenaline was relatively constant $29.9 \div 4.0 \%$ of that during the 1 st procedure, the value taken as control. There were marked increases in the heart rate during the both procedures. The initial heart rate was $100 \pm 4 / \mathrm{min}$. The percent increase in chronotropic response to each $30 \mathrm{sec}$ stimulation of the 1 st procedure was $64.2 \pm 6.0,64.7 \pm 4.3,61.3 \pm 3.5,55.6 \pm 5.0,54.6 \pm 4.9$ and $55.8 \pm 7.2$. The heart rate returned to normal within a few min after the 1 st procedure was over and was $91 \pm-3$ before the 2 nd procedure. Chronotropic responses to the 2 nd proccdure were much the same as those of the 1st procedure and are shown in circles of Fig. 1-A as a \% of the corresponding response to the 1 st procedure (left ordinate). The coronary flow decreased by 5 to $10 \%$ during the both procedures. These results are consistent with those in a previous report (6).

After the lst procedure, hearts were perfused with a test solution prepared by an addition of LiCl $14.3 \mathrm{mM}$ in Fig. 1-C. The heart rate after the solution was changed and the coronary flow during both procedures was the same as observed in the untreated hearts. The output of noradrenaline decreased to $18.2 \pm 1.9 \%$ of that before the perfusion, the value being significant $(P<0.01)$ from control. Each chronotropic response decreased progressively, the

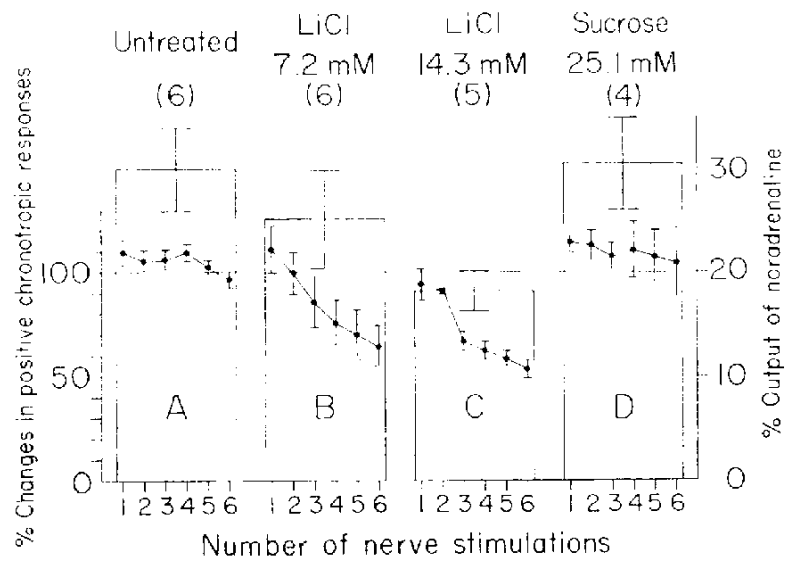

Fig. 1. Effects of lithium on adrenergic transmission in isolated rabbit hearts.

Sympathetic nerve was stimulated 6 times (the 1st procedure), each of 30 sec duration with $30 \mathrm{sec}$ resting period, during perfusion with untreated Krebs solution. Thereafter, hearts were perfused with a test solution prepared by an addition of LiCl or sucrose $(B$ to $D)$. In a similar manner the 2 nd procedure was started 24 min after changing the solution. Abscissa shows the number of each $30 \mathrm{sec}$ stimulation of both procedures. Heart beats were counted from 15 to 45 sec after the start of each 30 scc stimulation. The output of noradrenaline released (column) and cach positive chronotropic response (circle) during the 2 nd procedure are demonstratcd as a $\%$ of that during the 1 st procedure, respectively. The number of experiments is shown in parentheșes. Vertical bars indicate standard errors. 
3 rd to 6 th response being different $(P<0.01)$ from the corresponding response in untreated hearts, respectively. Decrease in the output of noradrenaline involved in the transmission blockade cannot be attributed to hypertonicity of the lithium solution, as there was no decrease in noradrenaline output following perfusion with an equi-osmotic medium containing sucrose (Fig. 1-D). Katz and Kopin (4) have shown that in brain slices of rats a lithium-induced inhibition of ${ }^{3} \mathrm{H}$-noradrenaline release evoked by electrical stimuli is prevented by raising the concentration of calcium. The site of the lithium action in rabbit hearts appears to be mainly in adrenergic nerve endings.

As shown in Fig. 1-B, the 4th to 6 th positive chronotropic response of $7.2 \mathrm{mM}$ lithium perfused hearts decreased significantly $(\mathrm{P}<0.05)$ from that in untreated hearts, at a time when the output of noradrenaline showed no difference $(25.1 \div 4.7 \%)$ from control. The decrease in chronotropic responses is not derived from the condition of repetitive nerve stimulation, as adrenergic transmission induced by a once only $30 \mathrm{sec}$ stimulation in rabbit atria was significantly inhibited $30 \mathrm{~min}$ after the addition of lithium $7.2 \mathrm{mM}$ (9). These results suggest that the major mechanism of the transmission blockade induced by lithium $7.2 \mathrm{mM}$ is of a post-synaptic origin.

In Table 1, peak positive responses were observed within 1 min of noradrenaline injection and 1 to $3 \mathrm{~min}$ after isoproterenol injection. Before perfusion with $7.2 \mathrm{mM}$ lithium solution, the duration of noradrenaline actions was 4 to $9 \mathrm{~min}$ and that of joproterenol was 11 to $20 \mathrm{~min}$ or more in case of $4.0 \times 10^{-6} \mathrm{M}$. Peak responses to noradrenaline after lithium perfusion decreased in parallel with the transmission blockadc. The duration of the actions also decreased to 3 to 7 min. Chronic 1reatment with lithium was reported to

TABI.E 1. Positive chronotropic and contractile responses of rabbit hearts to exogenously applied noradrenaline or isoproterenol before (control) and $30 \mathrm{~min}$ after perfusion with the medium containing $\mathrm{LiCl} 7.2 \mathrm{mM}$

\begin{tabular}{|c|c|c|c|c|c|c|}
\hline & \multirow{2}{*}{ M } & \multirow{2}{*}{$\begin{array}{l}\text { No. of } \\
\text { hearts }\end{array}$} & \multicolumn{2}{|c|}{$\begin{array}{l}\text { Positive chronotropic } \\
\text { responses }\end{array}$} & \multicolumn{2}{|c|}{$\begin{array}{l}\text { Positive contractile } \\
\text { responses }\end{array}$} \\
\hline & & & Control & $\begin{array}{c}\text { After } \\
\text { LiC1 } 7.2 \mathrm{mM}\end{array}$ & Control & $\begin{array}{c}\text { After } \\
\text { LiCl } 7.2 \mathrm{mM}\end{array}$ \\
\hline \multirow{3}{*}{ dl-Noradrenaline } & $2.4 \times 10^{-5}$ & 4 & $17.1 \pm 3.9$ & $9.7 \perp 2.4$ & $44.9 \pm 8.6$ & $13.4 \pm 3.3^{* * *}$ \\
\hline & $4.9 \times 10^{-5}$ & 6 & $23.1 \div 2.8$ & $13.2 ! 2.7^{*}$ & $57.8 \ldots 6.3$ & $24,3 \pm 3.8 * *$ \\
\hline & $2.4 \times 10^{-4}$ & 6 & $58.9 \div 3.4$ & $43.6 \therefore 4.1^{*}$ & $96.6+6.6$ & $64,0 \pm 3.4^{* *}$ \\
\hline$-\ldots \ldots$. & $1.6 \times 10^{-7}$ & 7 & $18.0 \div 3.5$ & $8.9 \div 1.6^{*}$ & $28.5+4.8$ & $11.5: 3.8^{*}$ \\
\hline \multirow[t]{2}{*}{ 1-Isoproterenol } & $8.1 \times 10^{-7}$ & 7 & $34.4 \div 4.4$ & $15.0: 2.1^{\%+4}$ & $57.4 \perp-7.5$ & $29.3=4.8 * *$ \\
\hline & $4.0 \times 10^{-6 i}$ & 7 & $51.3 \div 5.9$ & $31.5 \pm 5.0^{*}$ & $67.5 \div 3.2$ & $44.3 \stackrel{1}{=} 7.7 *$ \\
\hline
\end{tabular}

The amine, a hydrochloride, was injected in the order from low to high dose into the aortic cannula. Intervals of injection were 6 to $9 \mathrm{~min}$ for noradrenaline and 8 to $20 \mathrm{~min}$ for isoproterenol. The concentration of injection solution is expressed in terms of $M$. Injection volume was $0.1 \mathrm{ml}$. Heart beats were counted for $30 \mathrm{sec}$, $15 \mathrm{sec}$ and every 1 min after injection. Peak responses are expressed as \% increases (mean-istandard error).

*: Significantly different from control, $\mathrm{P}<0.05$.

**: Significantly different from control, $P<0.01$. 
produce an increase in the uptake of ${ }^{3} \mathrm{H}$-noradrenaline in vitro by synaptosomes isolated from the rat brain (10). Lithium may thus be considered to increase noradrenaline uptake by adrenergic endings in the heart, which would in turn result in a decrease in the transmitter available for interaction with receptors. To rule out such a possibility, isoproterenol was used, as the amine is not a substrate for the neuronal uptake mechanism (11). Peak responses to isoproterenol after lithium perfusion also decreased in parallel with the transmission blockade. The duration of the actions decreased to 8 to 16 min. The results are consistent with the findings that positive inotropism as well as the activation of phosphorylase A by noradrenaline and isoproterenol decreased after perfusion with a $10 \mathrm{mM}$ lithium solution in guinca-pig hearts (12).

Thus it is concluded that the primary blocking action of lithium on the adrenergic transmission is not due to a decrease in the noradrenaline which interacts with receptors but rather to an inhibition of post-synaptic responses of the rabbit heart to the transmitter.

\title{
REFERENCES
}

1) Corrodi, H., Fuxe, K., Höklelt, T. And Schol, M.: Psychopharmacologia 11, 345 (1967);

2) Schanberg, S.M., Schildokaut, J.J. and Kopiv, I.J.: Biochem. Pharmacol. 16, 393 (1967):

3) Schildkrad , J.J., Logue, M.A. And Dodge, G.A.: Psychopharmacologia 14, 135 (1969):

4) Karz, R.I. ANd Kopin, I.J.: Biochem. Pharmacol, 18, 1935 (1969); 5) Segal, M.: Nathre 250, 72 (1974); 6) Misu, Y., And Kubo, T.: Japan. J. Pharmacol. 22, 359 (1972); 7) Garry, R.C. and Gilitespli, J.S.: J. Physiol. 128, 557 (1955); 8) Anton, A.H. avd Sayrf, D.F.: $J$. Phamacol. exp. Ther. 138, 360 (1962); 9) Misu, Y., Kuraishi, Y. And Takagr, H.: Japan. J. Pharmacol. 23, 891 (1973); 10) Colburn, R.W., Goodwin, F.K., Bunney, W.F., Jr. And Davis, J.M.: Nature 215, 1395 (1967); 11) IVERSIN, L.L. AND Callingham, B.A.: Fundamentals of Biochemical Pharmacology, Edited by BACQ, Z.M., CAPLK, R., PAOLETTI, R. AND RENSON, J., p. 253, Pergamon Press, Oxford, New York, Toronto, Sydney, Braunschweig (1971): 12) Fra7fr, A., Hancock, A., Misdeles, J. and Macintrke, R.: Biol. Pspchiat. 5, 79 (1972)

\section{QUANTITATIVE ASPECT OF ACID SECRETION RESPONSE OF ISOLATED BULLFROG GASTRIC MUCOSA PREPARA- TION: EFFECT OF SECRETAGOGUES AND INHIBITORS}

\author{
Yoshiaki GOTO and Kazuo WATANABE \\ Department of Pharmacometrics, Research Institute for Wakan-yaku, \\ Toyama University, Toyama 9.30, Japan
}

Accepted October I, 1975

In recent years, a considerable number of studies concerning the physiological functions of gastrointestinal hormones have been done (1-3). The gastric acid secretion is, however, subjected to complex neural and hormonal influences. Therefore, the simple experimental system using an isolated organ is necessary in order to elucidate the mechanisms of actions of the secretagogues on gastric acid secretion. The bullfrog (Rana catesbiana) gastric mucosa can be readily separated from the muscular layers without giving any injury to the 